Bioeduca: Journal of Biology Education
$\frac{\text { http://iournal.walisongo.ac.id/index.php/bioeduca }}{\text { ISSN 2714-8009 (print), 2715-7490 (online) }}$
Volume 2, Nomor 2, Tahun 2020
Hal. 87 - 100

\title{
Model Pengembangan Usaha Berbasis Lingkungan Kelompok Difabel di Kota Cirebon
}

\author{
Fifi Novianty ${ }^{1^{*}}$ \\ ${ }^{1}$ Komunikasi dan Penyiaran Islam, Universitas Islam Negeri Sunan Kalijaga Yogyakarta \\ *Email: noviafifi.nf@gmail.com
}

\begin{tabular}{|c|c|}
\hline Informasi Artikel & ABSTRAK \\
\hline $\begin{array}{l}\text { Submit: } 04-09-2020 \\
\text { Diterima: } 29-09-2020 \\
\text { Dipublikasikan: } 11-10-2020\end{array}$ & $\begin{array}{l}\text { Penyandang disabilitas di Kota Cirebon sering kali mengalami } \\
\text { kesulitan dalam mencari lapangan pekerjaan sehingga } \\
\text { membentuk warga peduli ekonomi difabel. Kelompok difabel } \\
\text { "Kula Eksis" dibentuk untuk memberdayakan kaum difabel. } \\
\text { Penelitian ini untuk meneliti model pengembangan usaha } \\
\text { berbasis lingkungan kelompok difabel Kota Cirebon. Metode } \\
\text { yang digunakan adalah kualitatif dengan pendekatan studi kasus. } \\
\text { Analisis menggunakan analisis grounded dan analisis domain. } \\
\text { Hasil penelitian menunjukkan model pengembangan usaha } \\
\text { berbasis lingkungan kelompok warga peduli ekonomi difabel } \\
\text { "Kula Eksis" Kota Cirebon terdapat empat model pengembangan } \\
\text { usaha yang berbasis pada kebutuhan difabel yaitu (1) kerajinan } \\
\text { dari barang bekas dan sampah plastik, (2) produk anyaman dari } \\
\text { bambu, (3) produk makanan, (4) pertamini. Terdapat dua kendala } \\
\text { yaitu kendala internal dan kendala eksternal. Model } \\
\text { Pengembangan usaha mampu memberikan perubahan bagi } \\
\text { kemajuan perekonomian kelompok difabel di Kota Cirebon. } \\
\text { Dampak model pengembangan usaha berbasis lingkungan yaitu } \\
\text { perekonomian difabel meningkat dan limpahan sampah plastik } \\
\text { menurun. } \\
\text { Kata kunci: difabel; lingkungan; model usaha; pengembangan. }\end{array}$ \\
\hline Penerbit & ABSTRACT \\
\hline $\begin{array}{l}\text { Program Studi Pendidikan } \\
\text { Biologi, Fakultas Sains dan } \\
\text { Teknologi, UIN Walisongo } \\
\text { Semarang }\end{array}$ & $\begin{array}{l}\text { Disabilities in Cirebon City often experience difficulties in finding } \\
\text { employment opportunities, thus forming citizens who care about } \\
\text { the economy with disabilities. The diffable group "Kula Eksis" was } \\
\text { formed to empower people with disabilities. This research is to } \\
\text { examine the environmental-based business development model } \\
\text { for the disabled group in Cirebon City. The method is qualitative } \\
\text { with a case study approach. Analysis using grounded analysis } \\
\text { and domain analysis. The results showed there are four models } \\
\text { of business development based on the needs of disabilities, } \\
\text { namely (1) handicrafts from used goods and plastic waste, (2) } \\
\text { woven products from bamboo, (3) food product, (4) pertamini. } \\
\text { There are two obstacles, namely internal constraints and external } \\
\text { constraints. The environmental-based business development } \\
\text { model that is applied is able to provide changes for the economic } \\
\text { progress of the disabled group in Cirebon City. The impact of the } \\
\text { environmentally based business development model is the } \\
\text { economy with disabilities increases and the abundance of plastic } \\
\text { waste decreases. } \\
\text { Keywords: development; difabel; environment; model business. }\end{array}$ \\
\hline
\end{tabular}

Copyright $(22020$, Bioeduca: Journal of Biology Education 


\section{PENDAHULUAN}

Potensi lokal merupakan kekayaan suatu daerah yang dapat dimanfaatkan sebagai bahan belajar mandiri bagi siswa (Destiara et al., 2018). Sesuai menurut (Prabowo et al., 2016) bahwa pengguna potensi lokal dalam pembelajaran dapat dikemas dalam bahan ajar berbasis Potensi lokal. Potensi lokal yang dimaksud yaitu berupa kekayaan keragaman jenis ikan yang terdapat di daerah Panjaratan.

Model pengembangan usaha dewasa ini semakin berkembang pesat. Usaha mikro maupun makro yang tersebar di setiap wilayah kota di Indonesia tentu memiliki model yang berbeda. Setiap kelompok usaha berlomba untuk menemukan inovasi baru dalam mengembangkan usahanya. Begitupula dengan kelompok difabel Kota Cirebon yang mengembangkan usaha berbasis lingkungan. Barang bekas dan sampah plastik disulap oleh kelompok difabel menjadi produk kerajinan bernilai jual tinggi. Usaha berbasis lingkungan dipilih kelompok difabel guna meminimalisir pencemaran lingkungan oleh limbah plastik. Kelompok difabel ini membuat kerajinan dan produk dari anyaman bambu serta barang-barang bekas. Didampingi oleh Dinas Sosial Kota Cirebon, kelompok difabel mampu bersaing dengan produk lain. Karena melihat sulitnya mencari lapangan pekerjaan bagi kaum difabel, Dinas Sosial membuat kelompok warga peduli ekonomi difabel Kota Cirebon.

Banyak orang yang tidak mengetahui banyak kaum difabel yang memiliki prestasi dan dapat melakukan hal yang tidak sempat dipikirkan oleh orang lain. Dalam hubungan sosial di dunia nyata, terkadang kaum difabel mendapatkan perlakuan yang berbeda dan sering dipandang sebelah mata. Bukan hanya di lingkungan sosial saja, ketika seseorang yang menyandang disabilitas ingin mencari pekerjaan juga mengalami kesulitan karena terkendala oleh persyaratan dalam melamar pekerjaan. Dari kendala tersebut perekonomian kaum difabel masih bergantung pada sanak saudara dan keluarga terdekat. Sulitnya mencari lapangan pekerjaan bagi kaum difabel menjadi penyebab kemiskinan dan memunculkan masalah ekonomi di kalangan difabel.

Penyandang disabilitas memiliki banyak wajah dan terdapat dalam banyak bentuk. Setiap kaum difabel mengalami perlakuan yang berbeda dalam lingkungannya atau dalam menjalin hubungan sosial. Salah satu contoh dari perlakuan berbeda adalah sarana dan prasarana yang masih belum memadai bagi kaum difabel. Berdasarkan penelitian Anisa Kusuma Wardani disebutkan sarana prasarana peradilan seperti di kantor kepolisian, kejaksaan, dan kantor hakim belum mudah diakses (accesable) bagi penyandang disabiltas. Sarana prasarana fisik dan non fisik tidak ada atau tidak terfasilitasi sama sekali (Wardani, 2014).

Kaum difabel diperlakukan berbeda dengan orang yang tidak memiliki kebutuhan khusus, sehingga sebagian orang memandang negatif kaum difabel atas keterbatasan fisik dan perbedaan yang dimiliki. Pandangan negatif sebagian besar masyarakat pada kaum difabel, selain menyulitkan kaum difabel untuk mencari pekerjaan juga menyulitkan mereka dalam hubungan sosial. Dalam kelompok kecil yang ada dalam lingkungan sosial, pertemuan antara kepentingan sosial dengan kepentingan individu, berlangsung secara tajam. Dalam kelompok kecil dibentuk karena ingin mengetahui 
tingkah laku individu dalam menghadapi kenyataan- kenyataan sosial. Mereka yang merasa terdiskriminasi dalam masyarakat, biasanya membentuk sebuah kelompok kecil. Kelompok kecil dibentuk karena memiliki nasib dan tujuan yang sama (Soekanto, 2012).

Menjawab kegelisahan dari permasalahan sosial dan ekonomi yang dihadapi kaum difabel di Kota Cirebon, terdapat kelompok difabel yang mengembangkan sebuah usaha ekonomi bernama "Kula Eksis". Pengembangan usaha yang dikembangkan oleh tersebut adalah pengembangan usaha berbasis lingkungan.

Pembentukan kelompok warga peduli difabel Kota Cirebon berawal dari kepekaan dan kepedulian Kepala UPT Liposos Panti Persinggahan dan LBK Kota Cirebon bernama Astawi, SE. Pada 28 Juli 2019 kaum difabel dikumpulkan untuk diberikan pelatihan dan keterampilan soft skill guna meningkatkan kesejahteraan dan perekonomian kaum difabel di Kota Cirebon. Pada awal pengembangan usaha kelompok difabel, kepala UPT menggunakan modal pribadinya tanpa bantuan dana dari Pemerintah. Modal tersebut digunakan untuk pengembangan usaha pom bensin mini "Pertamini" yang menghabiskan dana sekitar Rp 12 Juta, sedangkan biaya yang harus dikeluarkan untuk pengembangan usaha kelompok difabel "Kula Eksis" Kepala UPT Liposos menghabiskan dana sekitar Rp 8 Juta (Arif, 2020).

Program "Kula Eksis" diperuntukan bagi kaum difabel agar mampu bersaing dan dapat hidup mandiri dalam mengembangkan perekonomian. UPT Liposos bersama Dinas Sosial Kota Cirebon berusaha terus meningkatkan pelayanan bagi kelompok difabel dengan mengadakan pelatihan soft skill. Pelatihan dan pendampingan dilakukan dengan cara mengundang pemateri atau pelatih keterampilan dari luar lembaga seperti dari alumni Panti Persinggahan (panti khusus untuk disabilitas), PT. Segi Tiga Biru untuk pelatihan membuat makanan dan lain- lain. Dilihat dari beberapa faktor pembentuk kelompok sosial, maka dapat dipastikan terbentuknya kelompok difabel adalah untuk mencapai tujuan bersama yaitu demi kemajuan perekonomian dan kesejahteraan kaum difabel di Kota Cirebon. (Abdulsyani, 2007).

Kelompok ekonomi peduli difabel tersebut dapat memberi semangat bagi kaum difabel dan merubah cara pandang masyarakat yang memandang kaum difabel sebelah mata. Dibentuknya usaha "Kula Eksis" dalam kelompok ekonomi peduli difabel di Kota Cirebon dapat menjadi solusi yang tepat untuk meminimalisir kemiskinan karena begitu sulitnya persaingan dan terhalang oleh persyaratan yang harus dipenuhi dalam mencari pekerjaan bagi kaum difabel. Dinyatakan dalam penelitian bahwa pemberdayaan bisnis kaum difabel adalah agar membuat kaum difabel menjadi lebih mandiri serta tidak bergantung pada orang lain. Pemberdayaan ini bisa dilakukan dengan cara penggalian potensi terhadap diri seseorang. Pemberdayaan itu mendapat nilai tambah ketika ditunjukan pada kaum difabel. Salah satu pemberdayaan kaum difabel yang pernah dilakukan adalah pemberdayaan di bidang bisnis madu, karena pada masa lampau kaum difabel tersebut telah bekerja dalam bisnis madu. Kaum difabel tersebut melakukan banyak inovasi, sehingga bisnis madunya bertambah maju (Widiantoro, 2016). 
Hasil penelitian lainnya mengenai pengembangan ekonomi kaum difabel di Yogyakarta yaitu adanya lima cabang industri utama yang berkembang. Cabang industri tersebut yaitu, industri pangan memiliki unit usaha yang paling besar, diikuti

usaha kerajinan, kimia dan bahan bangunan, sandang dan kulit, dan unit usaha terkecil yaitu pada industri logam dan elektronik. Sedangkan bidang industri kreatif unggulan yang akan dikembangkan lebih lanjut di Yogyakarta yaitu industri kerajinan, fashion, permainan interaktif, desain dan pelayanan computer (Shidiq, 2017).

Faktor yang berperan melahirkan kreativitas seorang difabel berdasarkan hasil penelitian yakni (1) faktor keluarga karena sebagian besar waktu yang dihabiskan seorang difabel adalah bersama keluarga, (2) faktor kebutuhan psikologis karena sama seperti manusia lain yang membutuhkan kebutuhan sandang, pangan dan papan maka kebutuhan psikologis juga dapat menumbuhkan kreativitas difabel untuk terus bisa memenuhi kebutuhannya, (3) faktor idola yang dikagumi yaitu ketika seorang difabel memiliki sosok idola yang dikagumi, maka ia akan berusaha seperti idolanya, (4) faktor teman dekat, artinya teman dekat sangat penting dalam memotivasi dan menumbuhkan kreativitas kaum difabel karena sekelompok orang yang memiliki nasib biasanya memiliki tujuan yang sama, dan (5) faktor ingin berubah lebih baik (Saniscara, 2011).

Penelitian yang sama dalam pengembangan kemandirian kaum difabel juga dilakukan oleh Setyaningsih dkk (2016) di Kabupaten Sukoharjo bahwa banyak permasalahan yang dialami oleh difabel mulai dari permasalahan sosial, ekonomi, psikologi, budaya, pendidikan, hingga aksesibilitas. Stereotip masyarakat yang memandang difabel sebagai kaum lemah membuat difabel termarjinalkan dalam kehidupan bermasyarakat. Paguyuban difabel di Kabupaten Sukoharjo. Memiliki peran meningkatkan kemandirian para difabel (Setyaningsih, 2016).

Berdasarkan paparan diatas, maka perlu dilakukan penelitian mengenai model pengembangan industri kelompok warga peduli ekonomi difabel di Kota Cirebon. Penelitian ini ingin meneliti lebih dalam mengenai model usaha-usaha berdasarkan jenis industri yang sesuai dengan kebutuhan dari kaum difabel di Kota Cirebon serta pemetaan pengembangan usaha yang dilakukan oleh kelompok warga peduli ekonomi difabel di Kota Cirebon.

Dari pemetaan jenis model pengembangan usaha kelompok warga peduli difabel, maka diharapkan dari penelitian ini dapat bermanfaat bagi masyarakat dan khususnya bagi penyelenggara yaitu pemerintah kota untuk lebih memaksimalkan program yang dikhususkan untuk kaum difabel yaitu dengan mengetahui model usaha yang berbasis pada kebutuhan kaum difabel di Kota Cirebon. Penelitian ini juga diharapkan dapat bermanfaat untuk dijadikan referensi bacaan bagi peneliti berikutnya.

\section{METODE PENELITIAN}

Metode yang digunakan dalam penelitian ini adalah kualitatif dengan pendekatan studi kasus. Teknik pengumpulan data adalah observasi, wawancara dan dokumentasi. Teknik pengumpulan data secara wawancara yaitu peneliti melakukan 
pengumpulan data dengan mewawancarai Dinas Sosial Kota Cirebon, anggota kelompok difabel "Kula Eksis" dan LSM yang terkait dalam pengembangan usaha kelompok "Kula Eksis" Kota Cirebon.

Penelitian ini menggunakan sampel yang representatif dengan metode cluster sampling. Kerangka analisis dapat dijelaskan bahwa dalam penelitian ini adalah analisis grounded, yaitu peneliti langsung dengan tanpa membawa rancangan konseptual, teori dan hipotesis tertentu untuk menghindari terjadinya studi verifikatif yang cenderung memaksakan level empiris dengan dataran konseptual. Grounded research adalah metodologi penelitian kualitatif yang menekankan penemuan teori dari data observasi empirik di lapangan dengan metode induktif (Sudira, 2009). Pendekatan grounded theory merupakan metodologi umum analisis terkait dengan pengumpulan data sistematis yang diterapkan dan menggunakan serangkaian metode untuk menghasilkan sebuah teori induktif tentang area substantif. Metode grounded theory dimulai dari data untuk mencapai sesuatu teori dan bukan dimulai dari teori atau untuk menguji suatu teori (Sudira, 2009).

Analisis kedua adalah analisis domain yaitu bertujuan menjawab permasalahan yang cukup luas untuk mendapatkan gambaran yang seutuhnya dari objek yang diteliti dalam unsur yang sangat detail. Analisis domain pada hakikatnya merupakan upaya peneliti untuk memperoleh gambaran umum tentang data untuk menjawab fokus penelitian. Caranya adalah dengan membaca naskah data secara keseluruhan untuk memperoleh domain atau ranah apa saja yang ada di dalam data tersebut. Dari hasil pembacaan tersebut diperoleh hal-hal penting dari kata, frase atau bahkan kalimat untuk dibuat catatan pinggir (Rahardjo, 2010: 40).

\section{HASIL PENELITIAN DAN PEMBAHASAN}

Terbentuknya kelompok warga peduli difabel Kota Cirebon berawal dari kepekaan dan kepedulian dari Astawi, SE yaitu Kepala UPT Liposos, Panti Persinggahan, dan LBK Kota Cirebon. Pada 28 Juli 2019 dengan mengumpulkan kaum difabel untuk diberikan pelatihan dan keterampilan soft skill guna meningkatkan kesejahteraan dan perekonomian kaum difabel di Kota Cirebon. Pada awal pengembangan usaha kelompok difabel, Kepala UPT menggunakan modal pribadinya tanpa bantuan dana dari Pemerintah. Modal tersebut digunakan untuk pengembangan usaha pom bensin mini "Pertamini" yang menghabiskan dana sekitar Rp 12 Juta. Biaya yang harus dikeluarkan untuk pengembangan usaha kelompok difabel "Kula Eksis" Kepala UPT Liposos menghabiskan dana sekitar Rp 8 Juta (Arif, 2020).

Kepala Bidang Sosial DSPPPA Kota Cirebon, Ariya Dipahandi, SH, MKn menyatakan bahwa dalam program yang dijalankan oleh kelompok difabel "Kula Eksis" terdapat dua sektor perekonomian yang menjadi fokusnya yaitu di bidang makanan dan penjualan bahan bakar untuk kendaraan bermotor "Pertamini".

Kelompok "Kula Eksis" kini dapat bersaing dengan usaha di sektor makanan lainnya. Beberapa produk makanan nya adalah berupa kue nastar, stik keju dan kue kering lainnya. pemasarannya pun selain dari mulut ke mulut, produknya sudah masuk ke minimarket lokal dan banyak dapat permintaan dari tokoh-tokoh ritel. Pihak lain 
yang terkait dalam pengembangan usaha kelompok warga peduli ekonomi difabel adalah Dinas Perindustrian dan Perdagangan Kota Cirebon siap membantu kelompok warga peduli ekonomi difabel, untuk memfasilitasi dalam pembuatan merk, pengemasan dan pemasaran produk.

Proses pengembangan usaha kelompok warga peduli ekonomi difabel Kota Cirebon, juga harus menghadapi beberapa kendala. Berdasarkan yang diungkapkan oleh Kepala Bidang Sosial Dinas sosial Pemberdayaan Perempuan dan Perlindungan Anak (DSPPPA) Kota Cirebon, Ariya Dipahandi, SH, MKn, bahwa dalam perjalanan "Kula Eksis" banyak kendala yang harus dihadapi. Kendala yang pertama adalah dari SDM nya yakni anggota difabel terkadang mood-nya berubah- ubah sehingga ini mempengaruhi kuantitas produksi usaha makanan yang ingin dipasarkan sehingga ketika permintaan pasar akan kue produksi "Kula Eksis" meningkat, namun kewalahan dalam proses produksi karena kesediaan para difabel yang masih terganggu oleh perubahan mood. Kedua, kendala yang dihadapi "Kula Eksis" adalah dari anggota "Kula Eksis" yang sudah menikah, jarang mengikuti kegiatan atau pelatihan yang diberikan kepada "Kula Eksis", sehingga Kepala UPT Liposos dan Kepala Bidang Sosial DSPPPA Kota Cirebon, bulan Februari 2020 ingin menambah anggota "Kula Eksis" dari Yayasan Difabel Mekar Arum Kota Cirebon. Sepuluh anggota yang terpilih dari Yayasan Difabel Mekar Arum akan bergabung dalam kelompok warga peduli ekonomi difabel "Kula Eksis" dan akan diberikan pelatihan soft skill.

Hambatan lainnya yaitu menurunnya omset dari usaha "Pertamini". Hal ini dikarenakan banyak masyarakat yang lebih berminat untuk membeli bahan bakar kendaraan bermotor langsung ke pom bensin besar. Dari omset yang mulai menurun, semangat kaum difabel untuk mengembangkan usaha sempat menurun. Namun, Dinas Sosial Kota Cirebon beserta lembaga yang terkait selalu mengadakan pelatihan soft skill bagi pengembangan usaha perekonomian kaum difabel di Kota Cirebon. Pelatihan soft skill tersebut sangat berdampak bagi kelompok warga peduli ekonomi difabel, sehingga kini rasa percaya diri yang sempat turun dan kemauan untuk maju sudah bangkit kembali.

Dinas Sosial Kota Cirebon menginginkan kaum difabel dapat bersaing dengan masyarakat pada umumnya. Walaupun dalam pengembangan usaha kelompok warga difabel memiliki kendala, namun Dinas Sosial Bidang Pemberdayaan Perempuan, dan Perlindungan Anak (DSP3A) Kota Cirebon, UPT Liposos, Panti Persinggahan (Panti khusus penyandang difabel) terus melakukan pengembangan kelompok "Kula Eksis" dengan mengadakan pelatihan soft skill rutin untuk anggota difabel yang diadakan setiap satu bulan sekali. Kegiatan pelatihan ini bertujuan untuk meningkatkan kualitas pelayanan, sarana dan prasarana rehabilitasi kesejahteraan sosial bagi Penyandang Masalah Kesejahteraan Sosial (PMKS).

\section{Karakteristik Masyarakat Difabel Kota Cirebon}

Jumlah difabel dan jenis difabel di Kota Cirebon dari data yang diperoleh dari Dinas Sosial pada tahun 2016 menunjukan jumlah keseluruhan difabel di Kota Cirebon berjumlah 1327. Pada tabel 1 ditunjukkan bahwa jenis difabel yang ada 
terbagi menjadi delapan jenis difabel, yakni: Tuna Rungu (TR) berjumlah 127 orang, Tuna Wicara (TW) berjumlah 69, Tuna Daksa (TD) berjumlah 297, Tuna Netra (TN) berjumlah150 orang, Cacat Mental (CM) berjumlah 309 orang, Mantan Penderita Gangguan Jiwa (MPGJ) berjumlah 104, Orang Dengan Kecacatan Ganda (ODKG) berjumlah 220, dan Orang Dengan Kecacatan Berat (ODKB) berjumlah 51 orang. Dari data tersebut jenis difabel yang paling banyak di Kota Cirebon adalah Orang

Dengan Kecacatan Ganda (ODKG) yang berjumlah 220 orang. ODKG adalah orang yang memiliki kecacatan lebih dari 1 , seperti contohnya orang yang menderita tuna rungu sekaligus menderita tuna netra termasuk jenis difabel ODKG.

Tabel 1. Komposisi Jumlah Difabel dan Jenis Difabel di Kota Cirebon Tahun 2016

\begin{tabular}{|c|c|c|c|c|c|c|c|c|c|c|c|}
\hline \multirow{2}{*}{ NO } & \multirow{2}{*}{ KECAMATAN } & \multirow{2}{*}{ KELURAHAN } & \multicolumn{8}{|c|}{ JENIS KECACATAN } & \multirow{2}{*}{ KET } \\
\hline & & & $T R$ & TW & TD & TN & $\mathrm{CM}$ & MPGJ & ODGK & $\overline{O D K B}$ & \\
\hline 1 & HARJAMUKTI & 5 & 42 & 25 & 114 & 42 & 95 & 29 & 65 & 19 & \\
\hline 2 & KEJAKSAN & 4 & 18 & 10 & 34 & 27 & 38 & 11 & 40 & 9 & \\
\hline 3 & KESAMBI & 5 & 22 & 15 & 38 & 22 & 64 & 16 & 37 & 9 & \\
\hline 4 & LEMAHWUNGKUK & 4 & 35 & 10 & 77 & 37 & 64 & 38 & 60 & 10 & \\
\hline 5 & PEKALIPAN & 4 & 10 & 9 & 34 & 22 & 48 & 10 & 18 & 4 & \\
\hline & UUML АН & 22 & 127 & 69 & 297 & 150 & 309 & 104 & 220 & 51 & \\
\hline
\end{tabular}

KETERANGAN :
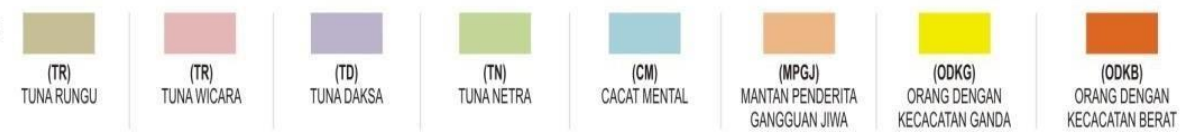

Sumber: Dinas Sosial Kota Cirebon

Dalam mengembangkan usaha kelompok warga peduli ekonomi difabel Kota Cirebon, kelompok "Kula Eksis" memiliki sepuluh anggota dengan jenis difabel tuna rungu, tuna wicara, dan fisik. Masing-masing difabel berasal dari beberapa Kelurahan yang ada di Kota Cirebon. Kepala UPT Liposos, Panti Persinggahan, dan LBK dengan Dinas sosial Pemberdayaan Perempuan dan Perlindungan Anak (DSPPPA) Kota Cirebon bekerja sama untuk memajukan usaha ekonomi dari kelompok "Kula Eksis" yang sudah berdiri sejak 28 Juli 2019. Dinas Sosial berencana menambah jumlah anggota "Kula Eksis" dengan merekrut alumni difabel dari Yayasan SLB (Sekolah Luar Biasa) Mekar Arum untuk diberikan pelatihan soft skill agar semakin banyak difabel yang memiliki potensi dan meningkatkan kepercayaan diri bagi kaum difabel.

Melihat peluang yang cukup besar dimiliki oleh kaum difabel, maka Dinas Sosial membentuk kelompok "Kula Eksis" yang mana kelompok ini akan diberikan pelatihan soft skill dan keterampilan dalam mengembangkan potensi yang dimiliki. Dinas Sosial bersama kepala Liposos Kota Cirebon, memberikan sarana dan prasarana bagi kelompok warga peduli ekonomi difabel "Kula Eksis", baik berupa materi maupun non materi. Bantuan dalam bentuk materi yang diberikan oleh Dinas Sosial digunakan untuk mengadakan pelatihan soft skill untuk para kelompok "Kula Eksis". Pelatihan di awal tahun 2020 Kepala Liposos menyatakan bahwa Dinas Sosial akan lebih 
memfokuskan pelatihan dalam bidang olahan makanan basah dan kering. Hal ini didasarkan pada permintaan pasar terhadap produk olahan makanan ringan "Kula Eksis" yang cukup banyak diminati oleh masyarakat Kota Cirebon.

Anggota kelompok difabel "Kula Eksis" memiliki kepercayadirian dan semangat belajar yang tinggi. Terbukti dari hasil wawancara peneliti dengan salah satu anggota "Kula Eksis" yang sedang mengikuti pelatihan soft skill pada awal tahun 2020 yang dihadiri oleh sepuluh anggota "Kula Eksis" di LPK Anidha. Menurut salah satu anggota yang memiliki keterbatasan fisik tuna netra melalui perantara penerjemah bahasa isyarat, menyatakan bahwa dirinya sangat bersemangat untuk mengikuti kegiatan pelatihan ini karena membuat dirinya lebih terampil dalam membuat sesuatu dan dapat mengisi waktu luang. Paparan dari salah satu anggota "Kula Eksis, melalui mentor penerjemah bahasa isyarat ketika ditemui dalam pelatihan soft skill di LPK Anidha sebagai berikut.

"saya senang sekali dapat bergabung dalam kelompok "Kula Eksis" dan dapat mengikuti pelatihan soft skill seperti belajar bikin olahan makanan ringan. Sesuai hobi saya masak-masak. Jadi saya bisa memanfaatkan waktu luang saya untuk hal yang lebih bermanfaat. Dan saya lebih percaya diri karena saya merasa bisa bersaing dengan orang normal pada umumnya. Karena dalam "Kula Eksis" kami saling menyemangati satu sama lain".

\section{Pengembangan Usaha Perekonomian Kaum Difabel}

Pengembangan usaha kelompok warga peduli difabel Kota Cirebon dibimbing dan diberikan pelatihan oleh Kepala UPT Liposos, Panti Persinggahan, dan LBK bekerjasama dengan Dinas sosial Pemberdayaan Perempuan dan Perlindungan Anak (DSPPPA) Kota Cirebon dengan mengadakan pelatihan soft skill berupa pelatihan membuat kue, menjahit, dan pelatihan sebagai penjual pom bensin mini "Pertamini".

Pelatihan soft skill di bidang olahan makanan ringan biasanya diadakan sebulan sekali. Diawal tahun 2020 kelompok "Kula Eksis" bersama Dinsos dan Kepala UPT Liposos, Panti Persinggahan, dan LBK bekerjasama dengan Dinas sosial Pemberdayaan Perempuan dan Perlindungan Anak (DSPPPA) Kota Cirebon mengadakan pelatihan soft skill bagi penyandang disabilitas "Tuna Wicara" dan "Tuna Fisik" yang berjumlah sepuluh anggota difabel. Kegiatan pelatihan i dilaksanakan dalam rangka pelatihan kerajinan anyaman bambu, kerajinan dari barang bekas, dan pengelolaan makanan basah dan kering yang diadakan di LPK Anidha Kota Cirebon. Kegiatan pelatihan merupakan kerja sama antara Dinas Sosial dengan LPK Anidha, dan narasumber yang memberikan pelatihan khusus dari LPK Anidha Kota Cirebon. Program pelatihan diadakan bertujuan untuk memperkuat soft skill bagi anggota kelompok difabel dalam mengelola usaha makanan riangan dan dari pelatihan ini dapat meningkatkan percaya diri bagi anggota kelompok difabel Kota Cirebon.

Data usaha yang dikembangkan oleh Dinas Sosial untuk kelompok "Kula Eksis" menunjukan keseragaman jenis usaha kreatif kelompok difabel Kota Cirebon fokus pada dua usaha yaitu usaha makanan dan usaha Pom Bensin Mini atau "Pertamini". Pelatihan yang diberikan untuk kelompok difabel diharapkan menjadi bekal bagi 
mereka dalam mengembangkan usaha yang dibimbing oleh Dinas Sosial. Selain itu pada kelompok "Kula Eksis" dalam menjalankan usaha produksi makanan ringan dengan bantuan pendampingan dari beberapa pihak seperti Dinas Sosial dan LSM terkait. Adapun pengelompokan jenis usaha yang dikembangkan oleh kelompok warga peduli ekonomi difabel "Kula Eksis" dapat dilihat pada tabel 2.

Tabel 2. Jenis Usaha Berbasis Lingkungan yang dikembangkan Kelompok Difabel Kota Cirebon

\begin{tabular}{|c|c|c|c|c|}
\hline No & Jenis Usaha & Klasifikasi Usaha & Status Usaha & Tahun \\
\hline 1 & $\begin{array}{l}\text { Produksi } \\
\text { Ringan }\end{array}$ & $\begin{array}{ll}\text { a. } & \text { Olahan Nasta } \\
\text { b. } & \text { Kue Lidah Kucing } \\
\text { c. } & \text { Peyek Kacang } \\
\text { d. } & \text { Kerupuk Nasi } \\
\text { e. } & \text { Keripik Talas } \\
\text { f. } & \text { Stik Keju }\end{array}$ & Aktif & $2019-2020$ \\
\hline 2 & $\begin{array}{lr}\text { Pom Bensin } & \text { Mini } \\
\text { "Pertamini" } & \text { ramah } \\
\text { lingkungan. } & \\
\end{array}$ & Pertamini ramah lingkungan & Aktif & $2019-2020$ \\
\hline 3 & $\begin{array}{l}\text { Produk Anyaman dari } \\
\text { Bambu (ramah } \\
\text { lingkungan) }\end{array}$ & $\begin{array}{l}\text { a. Tas anyaman bambu } \\
\text { b. Peralatan rumah tangga } \\
\text { anyaman bambu } \\
\text { c. Hiasan rumah anyaman } \\
\text { bambu }\end{array}$ & Aktif & $2019-2020$ \\
\hline 4 & $\begin{array}{l}\text { Kerajinan dari barang } \\
\text { bekas dan sampahplastik }\end{array}$ & $\begin{array}{l}\text { a. Tas dari barang bekas } \\
\text { b. Wadah Tisu dari limbah } \\
\text { plastik bekas bungkus kopi } \\
\text { dan minum serbuk } \\
\text { c. Rak buku dari barang } \\
\text { bekas }\end{array}$ & Aktif & $2019-2020$ \\
\hline
\end{tabular}

\section{Kendala dalam Pengembangkan Usaha "Kula Eksis"}

Menjalankan pengembangan usaha ekonomi peduli kelompok difabel "Kula Eksis", dinas sosial mengalami beberapa kendala dalam pengembangan usaha kelompok difabel. Kendala yang ada dapat diklasifikasikan menjadi dua jenis, yakni:

Kendala Internal yaitu kendala internal yang dihadapi oleh Dinas Sosial dalam pengembangan ekonomi difabel kelompok "Kula Eksis" adalah:

1. Terbatasnya dana dari pemerintah untuk mengembangkan usaha karena modal yang digunakan untuk pengembangan usaha kelompok "Kula Eksis" tidak sepenuhnya dari anggaran yang diberikan pemerintah, namun ada sebagian dari uang sukarelawan yang dikumpulkan menjadi satu kemudian digunakan sebagai modal usaha.

2. Memilih model pengembangan usaha yang cocok untuk diterapkan bagi kelompok difabel karena tak setiap usaha dapat dijalankan oleh kelompok difabel "Kula Eksis". Sebagai contoh pada tahun 2019 awal mula "Kula Eksis" terbentuk dibuat usaha "Pertamini" atau Pom Bensin mini, namun setelah beberapa bulan berjalan usaha "Pertamini" ini mengalami penurunan, karena selain kurang maksimalnya pelayanan juga kurangnya sarana dan prasarana yang memadai sehingga "Pertamini" produk "Kula Eksis" seiring berjalannya waktu kalah saing dengan Pom Bensin yang lebih besar. Sehingga hal tersebut membuat semangat anggota "Kula 
Eksis" sempat mengalami penurunan. Oleh karena itu Kepala UPT Liposos, Panti Persinggahan, dan LBK bekerjasama dengan Dinas sosial Pemberdayaan Perempuan dan Perlindungan Anak (DSPPPA) Kota Cirebon, di awal tahun 2020 berencana lebih memfokuskanbidang usaha kelompok ekonomi difabel "Kula Eksis" pada bidang usaha makanan ringan, karena lebih mudah dilakukan oleh kelompok difabel, lebih fleksibel dalam membagi waktu dan produk olahan makanan ringan yang dibuat oleh kelompok "Kula Eksis" sudah mendapat perhatian lebih dari masyarakat dan mendapat penilaian baik dalam masyarakat baik dari segi rasa maupun harga yang terjangkau.

Kendala Eksternal yaitu kendala yang muncul dalam kelompok difabel "Kula Eksis" yaitu:

1. Lingkungan masyarakat yang kurang mendukung pemasaran produk. Masih butuh waktu untuk penyesuaian dan pemasaran produk di lingkungan sekitar

2. Naik turunnya mood atau perasaan dari masing masing anggota "Kula Eksis", sehingga mengakibatkan terhambatnya proses produksi makanan yang ingin dikirim kepada konsumen.

3. Bagi anggota "Kula Eksis" yang sudah berkeluarga, mereka sulit untuk membagi waktu untuk keluarga dan untuk ikut kegiatan dalam kelompok "Kula Eksis", karena sebagian anggota yang sudah berstatus menikah sering absen atau tidak hadir ketika ada kegiatan pelatihan soft skill maupun ketika waktu produksi makanan yang nantinya akan dijual ke minimarket atau kepada masyarakat sekitar yang sudah memesan makanan ringan olahan "Kula Eksis". Kendala ini yang menjadikan Dinas Sosial ingin merekrut anggota baru untuk bergabung dalam kelompok "Kula Eksis" agar progres pengembangan usaha yang dijalankan oleh kelompok usaha peduli ekonomi difabel "Kula Eksis" Kota Cirebon dapat terus berkembang dan dapat mensejahterakan kehidupan kaum difabel di Kota Cirebon.

4. Daya dukung masyarakat belum merata. Pengembangan usaha kreatif sangat membutuhkan daya dukung masyarakat yang memadai. Usaha yang dikembangkan oleh kelompok "Kula Eksis" belum mendapat dukungan dari masyarakat secara merata, hanya beberapa masyarakat saja yang mengetahui produk olahan kelompok "Kula Eksis". Tidak meratanya daya dukung masyarakat juga dipengaruhi oleh keterbatasan pemasaran produk yang hanya mencakup beberapa wilayah saja. Keterbatasan tersebut membuat lemahnya daya dukung masyarakat terhadap produk usaha kelompok difabel "Kula Eksis".

5. Pergerakan terbatas. Keterbatasan dari kelompok difabel "Kula Eksis" menyebabkan pergerakan atau mobilitasnya sangat terbatas sehingga sangat sulit untuk mendapat akses mengenai informasi pemasaran produk, pengemasan produk, pendanaan, bahkan sulit untuk mendapatkan informasi lowongan pekerjaan untuk kaum penyandang difabel. Pemerintah telah membuat peraturan untuk kaum penyandang difabel agar mereka mendapatkan hak yang sama seperti masyarakat normal lainnya baik dalam porsi sebagai tenaga kerja di suatu perusahaan. Namun, karena keterbatasan pergerakan membuat kaum difabel sulit bekerja dalam sebuah perusahaan. 


\section{Pemetaan Model Usaha Kelompok Difabel}

Salah satu produk unggulan yang dikembangkan oleh "Kula Eksis" adalah produk makanan ringan, meski dalam pemasarannya masih terdapat kendala, namun Dinas Sosial bersama LSM terkait selalu memberikan pelatihan soft skill agar dalam pengembangan usaha kreatif milik "Kula Eksis" ini semakin maju dan dapat bersaing dengan olahan makanan yang diproduksi oleh pabrik maupun industri rumahan lainnya. Jenis-jenis komoditi industri unggulan di Kota Cirebon dapat dilihat pada tabel 3.

Tabel 3. Jenis-Jenis Komoditi Industri Unggulan Kota Cirebon Tahun 2018

\begin{tabular}{rlllll}
\hline No & \multicolumn{1}{c}{$\begin{array}{c}\text { Jumlah } \\
\text { Komoditi }\end{array}$} & $\begin{array}{c}\text { Unit } \\
\text { usaha }\end{array}$ & $\begin{array}{c}\text { Kapasitas } \\
\text { Produksi } \\
\text { (Rp 000) }\end{array}$ & $\begin{array}{c}\text { Nilai Produksi } \\
\text { (Rp 000) }\end{array}$ & $\begin{array}{c}\text { Nilai Investasi(Rp } \\
\mathbf{0 0 0 )}\end{array}$ \\
\hline 1 & $\begin{array}{l}\text { Meubel/ } \\
\text { Kerajinanrotan }\end{array}$ & 1.382 & 101.940 ton & 2.007 .360 .200 & 244.860 .199 \\
\hline 2 & Meubel kayu & 1.253 & 1.058 .394 Pcs & 364.613 .718 & 51.836 .013 \\
\hline 3 & Konveksi & 625 & 5.746 .800 pcs & 21.535 .245 & 16.440 .975 \\
\hline 4 & Batik & 593 & 42.024 kodi & 83.897 .693 & 14.003 .094 \\
\hline 5 & Makanan ringan & 770 & 19.200 ton & 23.122 .114 & 11.516 .427 \\
\hline 6 & Batu alam & 341 & $4.910 .131 \mathrm{~m} 2$ & 172.882 .201 & 11.321 .250 \\
\hline 7 & Kerajianan & 8 & 332.000 Pcs & 12.855 .000 & 1.363 .250 \\
& kulit kerang & & & & \\
\hline 8 & Sendal karet & 22 & 37.720 kodi & 4.455 .850 & 1.232 .719 \\
\hline 9 & Emping melinjo & 166 & 1.154 ton & 23.122 .114 & 881.963 \\
\hline
\end{tabular}

Sumber : Desperindag Kab.Cirebon 2018

Data diatas dilihat dari hasil penelitian, menyatakan bahwa pengembangan usaha kreatif yang berbasis kelompok difabel hanya masih bisa berkembang dalam komoditi roti dan makanan ringan serta komoditi emping melinjo. Sedangkan komoditi lain masih belum mendukung pada pengembangan usaha kreatif kelompok difabel.

Adapun yang menjadi potensi dari usaha berbasis lingkungan kelompok masyarakat peduli ekonomi difabel "Kula Eksis" akan dipetakan berdasarkan wilayah dan jenis usaha, sebagai berikut,

Tabel 4. Pemetaan Pengembangan Usaha Berbasis Lingkungan Kelompok Difabel "Kula Eksis"

\begin{tabular}{rll}
\hline No & \multicolumn{1}{c}{ Wilayah } & Pengembangan Usaha \\
\hline 1 & Harjamukti & Produksi Olahan Makanan Ringan, Produk Anyaman Bambu \\
\hline 2 & Kejaksan & Produksi Kerjainan barang bekas dan olahan Makanan Ringan \\
\hline 3 & Kesambi & $\begin{array}{l}\text { Produksi Kerajinan barang bekas dan olahan Makanan Ringan } \\
\text { dan Pertamini "Pom Bensin Mini”, ramah lingkungan }\end{array}$ \\
\hline 4 & Lemahwungkuk & Produksi Olahan Makanan Ringan \\
\hline 5 & Pekalipan & Produksi Olahan Makanan Ringan \\
\hline
\end{tabular}

Sumber: Hasil Wawancara dengan Dinas Sosial

Pemetaan pengembangan usaha berbasis lingkungan kelompok difabel "Kula Eksis" dilakukan dengan cara membagi wilayah daerah yang tersebar di Kota Cirebon dan menerapkan model pengembangan usaha kelompok difabel "Kula Eksis". Terdapat empat jenis pengembangan usaha kelompok warga peduli ekonomi difabel yaitu pengembangan usaha produk kerajinan barang bekas, kerajinan dari anyaman 
bambu, makanan ringan dan basah dan Pom Bensin Mini "Pertamini". Produk olahan makanan ringan dan basah dibagi menjadi beberapa produk yaitu,

1. Kerajinan dari barang bekas, diantaranya tas dari barang bekas, wadah tisu dari limbah plastik bekas bungkus kopi dan minum serbuk, dan rak buku dari barang bekas.

2. Produk kerajinan dari anyaman bambu, diantanya tas anyaman bambu, Peralatan rumah tangga anyaman bambu, Hiasan rumah anyaman bambu. Dan model pengembangan usaha berbasis lingkungan adalah Produk Anyaman Bambu. Bambu dimanfaatkan oleh kelompok difabel untuk dibuat produk kerajinan dan perlengkapan rumah tangga. Tentunya, semua produk anyaman bambu ini ramah lingkungan. Hal ini didukung penuh oleh Dinas Sosial, sebagai model pengembangan usaha berbasis lingkungan yang tentunya dapat mengurangi limbah plastik di Kota Cirebon.

3. Produk Olahan Makanan Kering, yaitu Nastar, Kue Lidah Kucing, Peyek Kacang, Kerupuk Nasi, Keripik Talas, Stik Keju. Produk Olahan Makanan Basah: olahan makanan berbahan baku singkong dan talas.

4. Pom Bensin Mini "Pertamini" ramah lingkungan.

Model pengembangan usaha berbasis lingkungan kelompok difabel Kota Cirebon Pertamini yang dikembangkan oleh kelompok difabel "Kula Eksis" hanya memiliki satu Pertamini. Proses menjalankan usahanya dengan cara Dinas Sosial memberikan pelatihan terkebih dahulu kepada kelompok difabel "Kula Eksis" untuk menjalankan atau mengoprasikan alat Pom Bensin Mini. Anggota kelompok Kula Eksis akan bergantian untuk menjaga Pertamini tersebut, yang letaknya ada diKesambi Kota Cirebon. Model usaha Pertamini ini masih terus dilakukan pengembangan dan pembaharuan dari Dinas Sosial agar bisa lebih baik dan efisien. Meningkatkan cara kerja bagi anggota kelompok difabel adalah cara Dinas Sosial agar "Pertamini" miliki kelompok difabel "Kula Eksis" dapat terus berjalan seiring banyaknya Pom Bensin umum yang lebih besar dan lebih cepat dalam hal pelayanan.

\section{SIMPULAN DAN SARAN}

Hasil penelitian menunjukan bahwa model pengembangan usaha berbasis lingkungan kelompok difabel Kota Cirebon lebih pada model usaha produk olahan makanan dan produk anyaman bambu yang ramah lingkungan. Model pengembangan usaha yang dikembangkan terdapat empat jenis yaitu produk kerajinan dari barang bekas dan sampah plastik, olahan makanan, pom bensin mini "Pertamini" dan produk anyaman bambu ramah lingkungan. Namun, model pengembangan usaha yang saat ini menjadi prioritas dan berbasis pada kebutuhan kelompok difabel "Kula Eksis" adalah model usaha produk olahan makanan. Model pengembangan berbasis kebutuhan kelompok difabel "Kula Eksis" memudahkan untuk mengembangkan usaha bagi kelompok difabel dan memajukan perekonomian bagi kelompok difabel "Kula Eksis". Pengembangan usaha berbasis lingkungan juga dapat menimalisir limbah sampah plastik. Sehingga model pengembangan usaha berbasis lingkungan sangat baik diterapkan di lingkungan Kota Cirebon. 


\section{UCAPAN TERIMA KASIH}

Ungkapan rasa terima kasih kepada Kepala UPT Liposos Panti Persinggahan dan LBK Kota Cirebon, Kepala Bidang Sosial Dinas sosial Pemberdayaan Perempuan dan Perlindungan Anak (DSPPPA), Pengelola Panti Persinggahan, Kelompok Kulo Eksis, dan pihak-pihak yang telah mendukung terlaksananya penelitian.

\section{RUJUKAN}

Abdulsyani. (2007). Sosiologi: Skematika, Teori dan Terapan. Jakarta: PT Bumi Akasara.

Aminah, S., Suprihatiningrum, J., \& Hanjarwati, A., (2015). Prodadisa Program Pemberdayaan Difabel Daksa Menuju Percontohan BKD (Balai Kerja Difabel) untuk Meningkatkan Kemandirian dan Life Skill Difabel”. Inklusi, 2(2), 298-342.

Arif. (2020). Memberdayakan Kaum Difabel Tetap Eksis. Diakses tanggal 23 Maret 2020 dari http://www.suaracirebon.com.

Budiasih, I. G. A. N. (2018). Metode Grounded Theory dalam Riset Kualitatif.Jurnal IImiah Akuntansi dan Bisnis. 9(1), 19-27.

Desperindag, Kab. Cirebon. (2018). Jenis-Jenis Komoditi Industri Unggulan Kota Cirebon Tahun 2018. Diakses tanggal 23 Maret 2020 dari, http://www.perdagin.cirebonkab.go.id.

Luthan, M. Z., Winandi, R., \& Rifin, Amzul. (2019). Analisis Pengembangan Model Bisnis Kanvas Perusahaan Hortikultura PT. XYZ. Forum Agribisnis: Agribusiness Forum, 9(2), 185-199. DOI. http://doi.org/10.29244/fagb.9.2.185-199

Mokalu, Frans. (2019). Ingin Eksis", Komunitas Difabel Cirebon Buka Kios Bensin. Diakses tanggal 17 Februari 2020 dari http://www.m.kbr.id.

Mukaromah, Kholila. (2012). Difabel dalam Perspektif Al-Quran (Kajian Tafsir Tematik). Skripsi. Jurusan Tafsir Hadits, Fakultas Ushuluddin, Studi Agama, dan Pemikiran Islam, UIN Sunan Kalijaga Yogyakarta.

Nopiah, Ririn. (2018). Dampak Sosial-Ekonomi Koperasi Difabel dan Perwujudan Microfinance Access. Diakses tanggal 8 Maret 2020 dari http://www.researchgate.net.

Rahardjo, Mudjia. 2010. Analisis Data Penelitian Kualitatif (Sebuah Pengalaman Empirik). Diakses tanggal 9 Maret 2020 dari http://www.uin-malang.ac.id.

Saniscara, D. I. (2011). Faktor Yang Berperan Dalam Melahirkan Kreativitas Besar Seorang Difabel (Studi pada Tarjono Slamet, Manajer Yayasan Penyandang Cacat Mandiri Craft Yogyakarta). Skripsi. Jurusan Bimbingan dan Konseling Islam, Fakultas Dakwah, UIN Sunan Kalijaga Yogyakarta.

Setyaningsih, R., Gutama. (2016). Pengembangan Kemandirian Bagi Kaum Difabel (Studi Kasus pada Peran Paguyuban Sehati dalam Upaya Pengembangan Kemandirian Bagi Kaum Difabel di Kabupaten Sukoharjo). Jurnal Sosiologi DILEMA, 31(1). 42-52.

Shidiq, S., Sudarsono, H., Mumpuni, S., Perdana, A.R.A. (2017). Model Pengembangan Potensi Industri Kreatif Pada Penyandang Difabel di D.I.Yogyakarta. prosiding SNaPP2017 Sosial, Ekonomi dan Humaniora. Hal. 458-469. pISSN 2089-3590. eISSN 2303-2472.

Soekanto, S. (2012). Sosiologi Suatu Pengantar. Jakarta: PT Raja Grafindo Persada.

Sudira, P. 2009. Studi Mandiri Grounded Theory. Diakses tanggal 8 Maret 2020 dari http://www.straffnew.uny.ac.id. 
Wardani, K. A. (2014). Akses Terhadap Hukum dan Peradilan Bagi Penyandang Disabiltas/Difabel. Diakses tanggal 9 Maret 2020 dari http://www.pprbm-solo.org.

Wawad, Sudirman. (2019). Pemkot Cirebon Libatkan Disabilitas Jadi Operator Pom Mini. Diakses tanggal 15 Februari 2020 dari http://www.m.detik.com.

Widiantoro, FX., W., Wartono., Shinta, A. (2013). Pemberdayaan Warga Difabel: Kunci Sukses Penggalian Potensi Dalam Bidang Bisnis. Seminar Nasional Psikologi "Aktualisasi Potensi Anak Bangsa Menuju Indonesia Emas". 